\title{
Preparation of Red Perylene Fluoroionophore Containing Calix[4]azacrown Ether and Their Ionophoric Properties
}

\author{
Young-Min Jeon, Tae-Ho Lim, Jong-Gyu Kim, Jong-Seung Kim ${ }^{\dagger}$ and Myoung-Seon Gong \\ Department of Chemistry and Institute of Basic Sciences, Dankook Chiversity, Chungnam 330-71 4 , Korea \\ "E-mail: msgongatalankookac.kr \\ ${ }^{\dagger}$ Department of Chemistry, Dankook Chimersity, Seoul $1+0-71+$, Korea \\ Received February 11, 2007
}

\begin{abstract}
Novel new red-light emitting pery lene fluoroionophore $N_{1} N^{\prime}$-dipropyl-1.7-bis(calix[4]azacrown-5-crown-5)3.4.9.10-perylene tetracarboxy dimide (3) was prepared by reacting $N_{1} N^{\prime}$-dipropyl-1.7-dibromo-3.4.9.10perylene tetracarboxy diimide (1) with calix[4]azacrown-5-crown-5. Also the alternating copolymer (4) with similar repeating unit was prepared reacting by calix[4]bisazacrown-5 with 1 . Metal ion binding by 3 and 4 leads to a blue-shift of absorption band and emission spectra. When ionophoric characteristics were investigated by binding alkali. alkali earth metal and various metal ions. polymeric ionophores displayed large fluorescence decreasing effects with $\mathrm{K}^{-}, \mathrm{Ag}^{-}$and $\mathrm{Ba}^{\hat{-}}$, which was rationalized by photo-induced charge transfer (PCT).
\end{abstract}

Key Words : Polymeric fluoroionophore. Perylene. PCT, Calix[4]-bisazacrown-5

\section{Introduction}

Sensing a positive ion has been a matter of great concern in chemists biologists. clinicians and environmentologists. Due to the selective complexation with metal ions. calix[4]crown ether has been widely applied to separate metal ions. In particular. it was reported that easy separation and high selectivity can be derived in case the cavity sizes of crown ethers are suitable to alkaline ions and alkaline-earth metal ions. $^{1-12}$ Calix[4]arene-based fluorescence sensors utilize photophysical changes produced by cation binding: photoinduced electron transfer. ${ }^{13-17}$ photoinduced charge transfer. ${ }^{18}$ excimer/exciplex formation and extinction. ${ }^{19}$ or energy' transfer. ${ }^{2 !}$ A 1.3 -alternate calis[4]crown platform provides a crown ether ring for metal ion complexation with the potential for additional binding by cation- $\pi$ interactions between the two rotated benzene rings and a polyethercomplexed metal ion. $: 1-24$

Perylene dye has been known as highly photostable pigments or vat dyes. " Perylenetetracarboxylic dimide derivatives have been studied because of their brilliant color. strong absorption and fluorescence and good thermal. chemical. and photochemical stability. ${ }^{2627} N N^{\prime}$-Dipropyl1.7-dibromo-3.4.9.10-perylene tetracarbosy dimide was adopted for the monomer having the red light-emitting fluorescent substance of which multi-chain has strong delocalization. However. in regards to selective sensing of specific metal ions. a few calix[4]arene-based polymer has been exploited. ${ }^{28-33}$

In this paper. we report on the syntheses of $N, N^{\prime}$-dipropyl1.7-bis(calix[4]azacrown-5-crown-5)-3,49.10-perylene tetracarboxy dimide (3) and its copolymer with same repeating unit and their photophysical properties upon metal ion complexation.

\section{Experimental Section}

Materials and Measurements. $N, N^{\prime}$-Dipropyl-1.7-dibromo-3.4.9.10-perylene tetracarboxy diimide (1) and $N, N^{\prime}$ dipropyl-1.7-bis(morpholino)-3.4.9.10-perylene tetracarboxy diimide (2) were prepared by the method previously reported ${ }^{2}$ Calix [4]bisazacrown-5 and calix[4]azacrown-5crown-5 in the 1.3-alternate conformation could be prepared in multi-steps from calix[4]arene. ${ }^{27}$ Acetonitrile was distilled over phosphorus pentoxide. Tetrahydrofuran and $N, N$-diisoprpopyl ethylamine (Aldrich Chem. Co.) were distilled over sodium and calcium hỳdride.

FT-IR spectra were obtained with a spectrophotometer (Biorad Excaliber FTS-3000MX) and ${ }^{~} \mathrm{H}$ NMR spectra were recorded on a spectrometer (Varian Unity Inova. $200 \mathrm{MHz}$ ). Elemental analyses were performed using a $\mathrm{CHN}$ analyzer (Yanaco MT-3). UV/Vis spectra were obtained on a spectrophotometer (Shimadzu 1601PC). Photoluminescence spectra were obtained on a spectrofluorometer (JASCO FP-6500).

Synthesis of $N, N^{\prime}$-Dipropyl-1,7-bis(calix[4]azacrown-5crown-5)-3,4,9,10-perylene tetracarboxy Diimide (3). A solution of $1(570 \mathrm{mg} .0 .90 \mathrm{mmol})$ and calix[4]azacrown-5crown-5 (2.0 g. 2.75 nmol) dissolved in THF $(20 \mathrm{~mL})$ was refluxed with stirring under argon in for $96 \mathrm{~h}$. After the solvent was removed by reduced pressure. then distilled water was added and the crude product was extracted with dichloromethane. After the solvent was removed by a rotary evaporator. and the product was purified by the column chromatograply based on the silica gel. Yield 95\%. FT-IR $\left(\mathrm{KBr} . \mathrm{cm}^{-1}\right) 3063$ (aromatic C-H). 2930. 2867 (aliphatic CH), $1675(\mathrm{C}=\mathrm{O}) .1131,1096(\mathrm{C}-\mathrm{O}$ and $\mathrm{C}-\mathrm{N}) .{ }^{\mathrm{l}} \mathrm{H}$ NMR ( $\mathrm{CDCl}_{3}$. ppm) 8.7-9.0 (m. 6H. ArH-perylene). 7.18-6.94 (m. 24H. 8 ArH-calix), 4.1-4.3 (m. 4H. 2 -N-CH-) 3.79 (s. 16H. $\left.8 \mathrm{Ar}-\mathrm{CH}_{2}-\mathrm{Ar}\right), 3.65-3.28$ (m. 56H. $24-\mathrm{OCH}_{2}$ and 4 
$-\mathrm{NCH}_{2}-$ ), 1.6-1.7 (m. 4H, $\left.2-\mathrm{CH}_{-}-\right), 0.9-1.0$ (s. $6 \mathrm{H}, 2-\mathrm{CH}_{3}$ ). Anal. Calcd for $\mathrm{C}_{118} \mathrm{H}_{128} \mathrm{~N}_{4} \mathrm{O}_{22}(1954.29)$ : C. $72.52 \%$ : $\mathrm{H}$. $6.60 \% ;$ N. $2.87 \%$. Found C, $72.41 \%$ : H, $6.47 \%$ : N, $2.83 \%$.

Synthesis of Copolymer with Calix[4]bisazacrown-5 (4). Calix[-4]-bisazacrown-5 (0.20 g, $0.27 \mathrm{mmol})$ and $1(0.17$ g. $0.27 \mathrm{mmol}$ ) were dissolved in the mixture of THF ( 20 $\mathrm{mL})$. and $N . N$-diisopropyl ethylamine $(0.30 \mathrm{~g} .2 .28 \mathrm{mmol})$. The solution was refluxed with stirring at $80^{\circ} \mathrm{C}$ for $72 \mathrm{~h}$ under argon. After the reaction mixture was precipitated in diethyl ether and the powdery product was filtered. The crude product was dissolved in dichloromethane and the solution was washed with distilled water several times. The resulting solution was reprecipitated in $n$-hexane. The yellow red powdery product was filtered and dried at $60^{\circ} \mathrm{C}$. Yield $81 \%$. FT-IR $\left(\mathrm{KBr} . \mathrm{cm}^{-1}\right) 3058.3023$ (aromatic C.H). 2862 (aliphatic $\mathrm{C}-\mathrm{H}), 1675(\mathrm{C}=\mathrm{O}), 1230(\mathrm{C}-\mathrm{O}$ and $\mathrm{C}-\mathrm{N}),{ }^{1} \mathrm{H}$ NMR ( $\mathrm{CDCl}_{3}$. ppm) 8.7-9.0 (m, 6H. ArH-perylene). 7.186.94 (m, 12H, ArH-calix). 4.1-4.3 (m. 4H, $\left.2-\mathrm{N}-\mathrm{CH}_{-}-\right), 3.79$ (s. $16 \mathrm{H}, 4 \mathrm{Ar}-\mathrm{CH}_{2}-\mathrm{Ar}$ ) $3.5-3.6$ (m. $32 \mathrm{H}, 8-\mathrm{O}-\mathrm{CH}_{2}=$ and 4 $\left.-\mathrm{N}-\mathrm{CH}_{2}-\right), 1.6-1.7\left(\mathrm{~m}, 4 \mathrm{H}, 2-\mathrm{CH}_{2}-\right), 0.9-1.0$ (s. $6 \mathrm{H} .2-\mathrm{CH}_{3}$ ). Anal. Calcd for $\mathrm{C}_{74} \mathrm{H}_{72} \mathrm{~N}_{4} \mathrm{O}_{12}(1209.40)$ : C. $73.49 \% ; \mathrm{H}$. $6.00 \%$; N. $4.63 \%$. Found C, $73.34 \%$ : H, $5.98 \%$ : N, $4.61 \%$.

General Procedure for Fluorescence Studies. The metal perchlorate or nitrate solution was prepared in acetonitrile at a concentration of $1.00 \mathrm{mM}$. Stock solutions of 3 and $+(0.06$ $\mathrm{mM}$ ) were prepared in acetonitrile. For all measurements. excitation was at $522 \mathrm{~nm}$ with excitation and emission slit widths at $3 \mathrm{~cm}$. Fluorescence titration experiments were performed using $6 \mu \mathrm{M}$ solutions of $\mathbf{3}$ and $\mathbf{4}$ in acetonitrile and various concentrations ( $1-3 \mathrm{eq}$.) of metal ion in acetonitrile.

\section{Results and Discussion}

The introduction of perylene to the calix[4]azacrown frame-work has been reported to produce a powerful binding site for metal ions. This led us to design calix[4]azacromnarmed perylene dye in which perylene links directly to azacrown loop links to the 1,3-alternate calix[4]arene framework. The synthetic scheme for preparing the calix[4]azacrown ether-amed perylene fluoroionophore is shown in Scheme 1.

Model fluoroionophore 3 containing perylene and calix[4]azacrown moiety were obtained by reacting 1 with calix[4]azacrown-5-crombl-5 in good yield as illustrated in Scheme $\mathrm{lb}$ ). Also the polymeric fluorophore 4 was prepared by polymerization of 1 with calix[4]bisazacrown- -5 in the presence of $N N$-diisopropyl etlyy lamine as shown in Scheme Ic). Total yield of polymer was found to be moderately high. To the best of our knowledge. these are the first example of alternating copolymer of calix[4]bisazacrown and perylene fluorophore. The product was confirmed by ${ }^{1} \mathrm{H}$ NMR. IR spectral assigument and elemental analysis. The incorporation of calix[4]azacrown into the polymer backbone enlances the solubility in conmon organic solvents to a high degree. When the solubility behavior of polymer was determined with powdered samples in excess solvent. the polymer was soluble in common organic solvents such as ethyl acetate. chloroform. acetonitrile while it displays virtually no solubility in $n$-hexane. methanol and ethyl ether.

The polymerization gave the polymer with somewhat moderate molecular weight judging from the data of viscosity and GPC. The polymer appeared to possess inherent
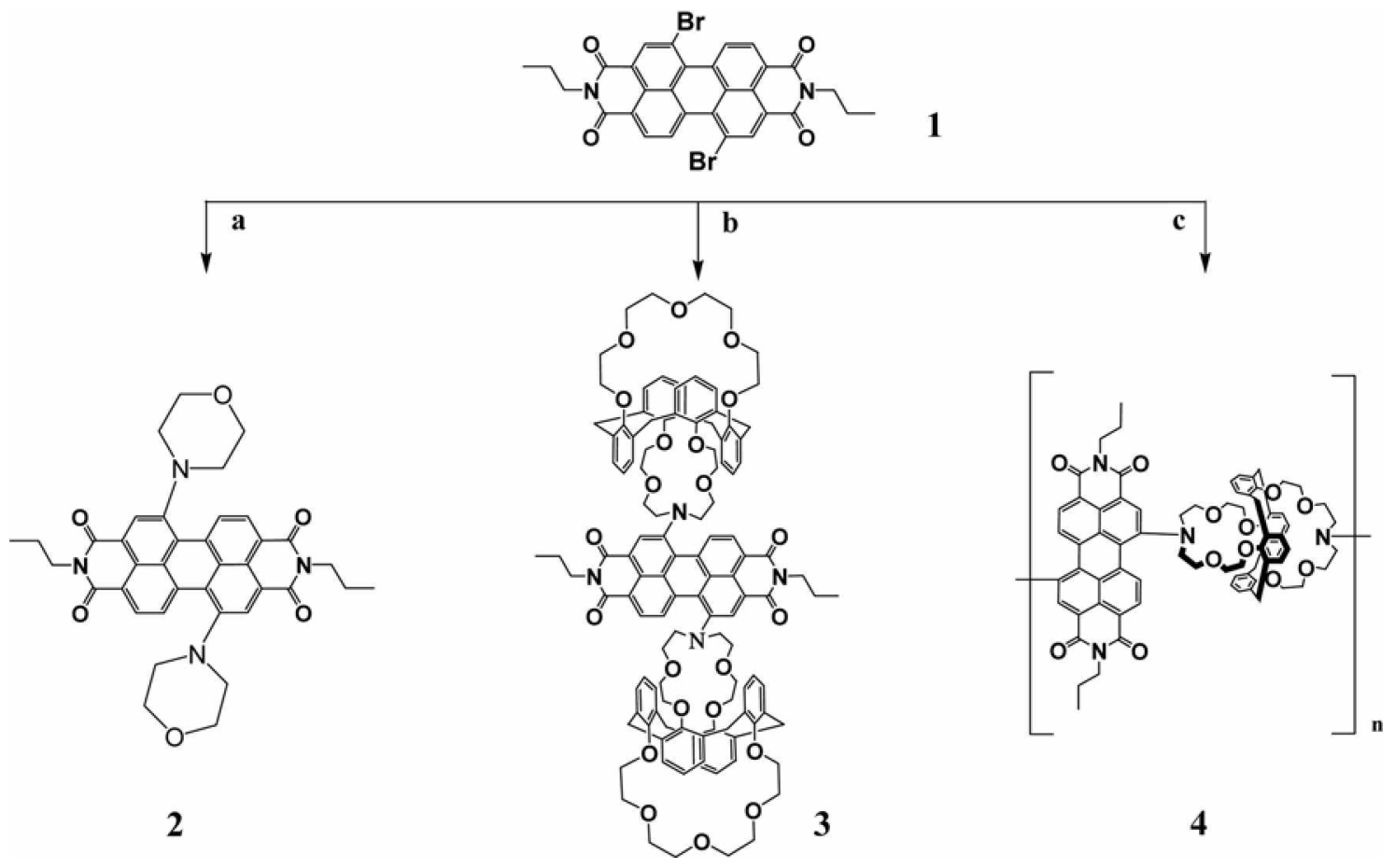

Scheme 1. Preparation of fluoroionophores containing perylene unit: a: morpholine, reflus, $72 \mathrm{~h}, 95 \%$; balis[ 4 ]azacrown-5-crown-5,

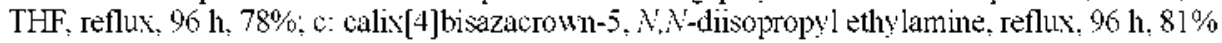


viscosity $0.38 \mathrm{dL} / \mathrm{g}$ and using chloroform at $25{ }^{\circ} \mathrm{C}$. The weight average molecular weight $11.200 \mathrm{~g} / \mathrm{mole}$ with a polydispersity index of 1.72 . Calix[4]bisazacrown-5 moiety often prevents the growing of the molecular weight due to the bulkiness. When the film was cast by allowing the solvent of the polymer 3 to evaporate on a glass, hard and brittle film was obtained.

3 and + exhibited absorption at $\hat{\lambda}_{\max }=517$ and 522 , and emission at $\hat{\lambda}_{\max }=537$ and $538 \mathrm{~nm}$ in acetonitrile. respectively. as shown in Figure 1. When a fluorophore contains anino group conjugated to an electron-withdrawing group.

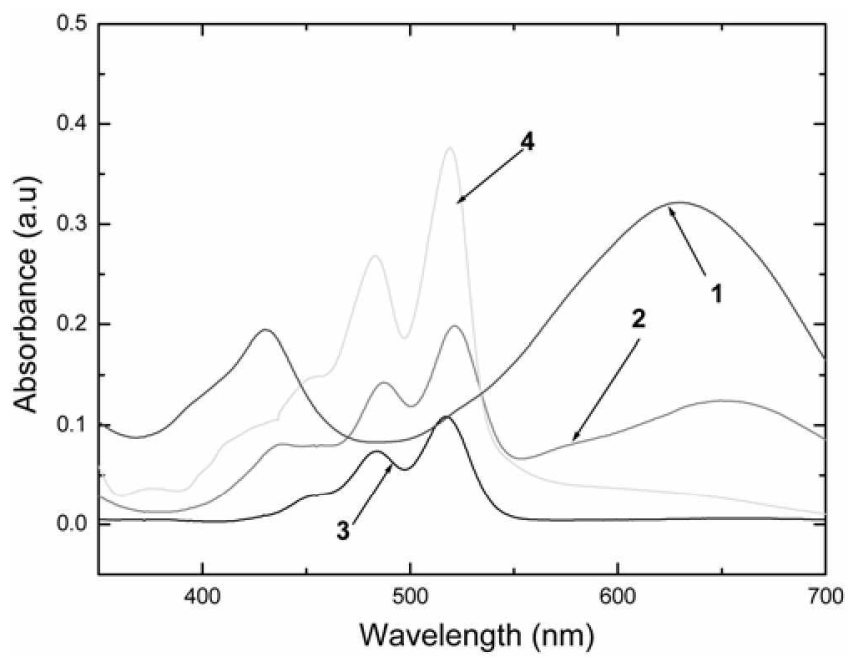

Figure 1. UV-visible absorption spectra of 1, 2, model fluorolonophore 3 and polymeric fluoroionophore 4 in acetonitrile.

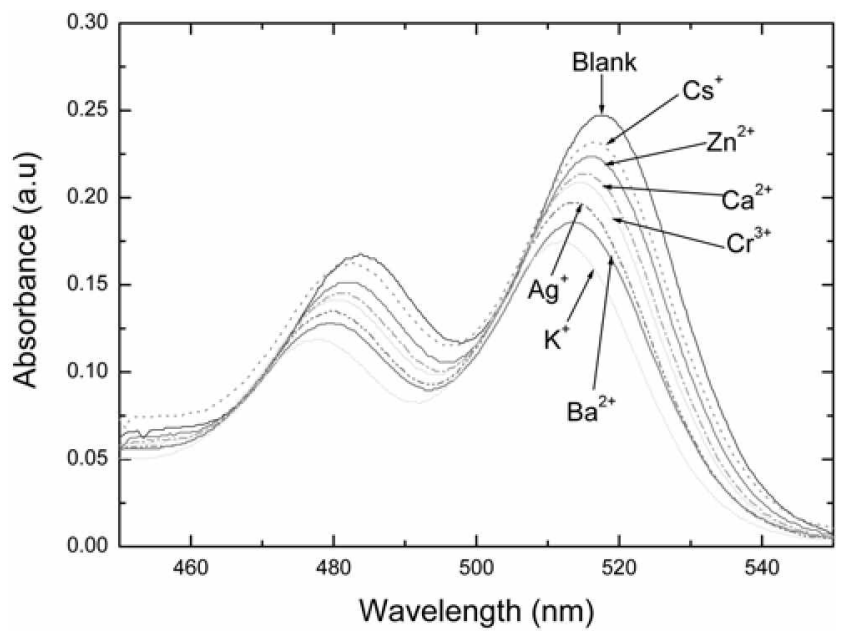

Figure 2. UV-visible spectral changes of $4(6 \mu \mathrm{M})$ accordmg to the complexation with various metal ions (3 eq). it undergoes intramolecular charge transfer from the donor to the acceptor upon excitation by light. Metal ion complexation is expected to cause the photophysical changes of the fluorophores such as wavelength shifts and intensity changes in absorption spectra as well as in fluorescence spectra. The absorption bands of 3 and 4 in the visible region are hypsochromically shifted $(1-4 \mathrm{~nm})$ by the complexation of metal ions. As shown in Figure 2, 4 shows a greater response to the $\mathrm{K}^{+}$and $\mathrm{Ba}^{2-}$ ion with which the wavelengths of the ligands move from 522 to $518 \mathrm{~nm}$ whereas it scarcely change with other metal ions.

To obtain insight into the binding properties of 3 and $\boldsymbol{A}$ toward metal ions, we investigated the fluorescence emission spectrum changes upon addition of various metal perchlo-

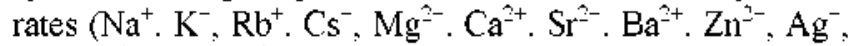
$\mathrm{Cu}^{-}, \mathrm{Al}^{2-}$, and $\mathrm{Eu}^{3-}$ ). Emission intensities change of 3 and 4 for various metal cations are summarized in Table 1 .

When the model fluoroionophore was bound with alkali metal ions. all the emission intensity decreased. 3 displayed a large fluorescence decreasing effect with $\mathrm{K}^{+}$and $\mathrm{Rb}^{-}$. whereas it scarcely change with $\mathrm{Na}^{+}$and $\mathrm{Cs}^{-}$ion. Thus 3 showed an even greater response to the $\mathrm{K}^{3-}$ ion with which the emission intensity decreased by $28 \%$ due to the crown ether bonded to the both sides of perylene dye as shown in Figure 3.

The photophysical changes upon cation binding can also be described in terms of charge dipole interaction. When divalent positive ion $\mathrm{Ba}^{3+}$ is added to the acetonitrile solution of 3 . the $\mathrm{Ba}^{2-}$ ion showed a $22 \%$ decrease in emission intensity. This fact is in good agreement with above conclu-

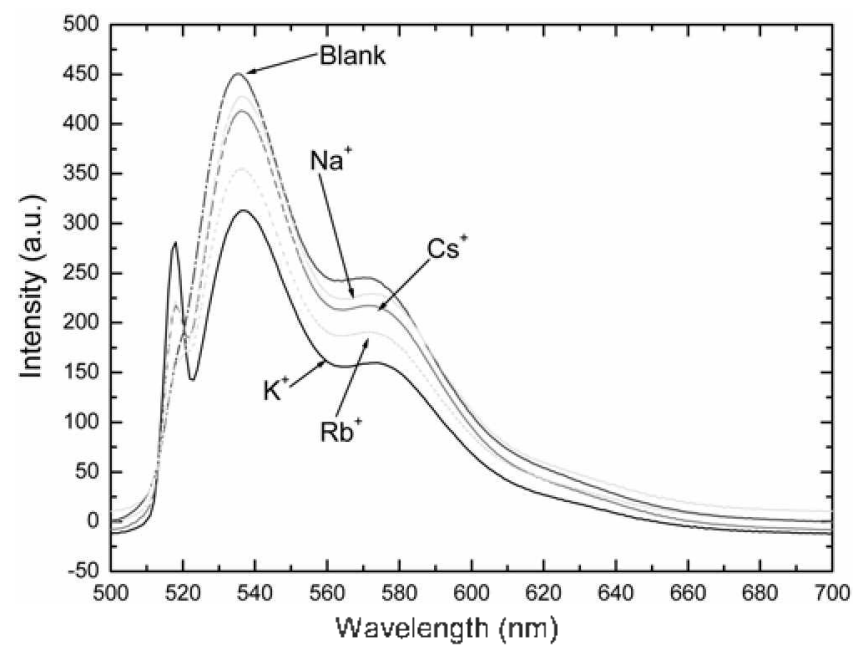

Figure 3. Fluorescence emission spectral changes of $3(6 \mu \mathrm{M})$ upon addition of alkali metals ions ( $3 \mathrm{eq})$.

Table 1. Enission Intensity Change of Perylene Fluoroionophore Containing Calis[4]azacrown-5 with Various Cations

\begin{tabular}{|c|c|c|c|c|c|c|c|c|c|c|c|c|c|c|c|}
\hline \multirow{2}{*}{ Product } & \multirow{2}{*}{$\frac{\text { Intensity }}{\text { Blank }}$} & \multicolumn{4}{|c|}{ I Group } & \multicolumn{4}{|c|}{2 Group } & \multicolumn{6}{|c|}{ etc. } \\
\hline & & $\mathrm{Na}^{+}$ & $\mathrm{K}^{-}$ & $\mathrm{Rb}^{+}$ & $\mathrm{Cs}^{+}$ & $\mathrm{Mg}^{\hat{-}}$ & $\mathrm{Ca}^{2-}$ & $\mathrm{Sr}^{2-}$ & $\mathrm{Ba}^{2+}$ & $\mathrm{Ag}^{+}$ & $\left.\mathrm{Al}\right|^{3-}$ & $\mathrm{Eu}^{3+}$ & $\mathrm{Zn1^{2- }}$ & $\mathrm{Cr}^{3-}$ & $\mathrm{Cu}^{+}$ \\
\hline 3 & 450 & 428 & 312 & 356 & 414 & 364 & 351 & 346 & 300 & 262 & 368 & 373 & 354 & 329 & 340 \\
\hline 4 & 614 & 560 & 436 & 508 & 538 & 545 & 594 & 512 & 503 & 460 & 546 & 556 & 553 & 594 & 546 \\
\hline
\end{tabular}

Maximum excitation wave length ( $\lambda_{\max }=517=1 \mathrm{~nm}$ ) and maximum emission wave length $\left(\lambda_{\max }=537=1 \mathrm{~nm}\right)$ for 3 . Maximum excitation wave length $\left(\vec{\lambda}_{\max }=522=1 \mathrm{~mm}\right)$. maximun enission wave length $\left(\lambda_{\max }=538 \pm 1 \mathrm{mmn}\right)$ for 4 . 


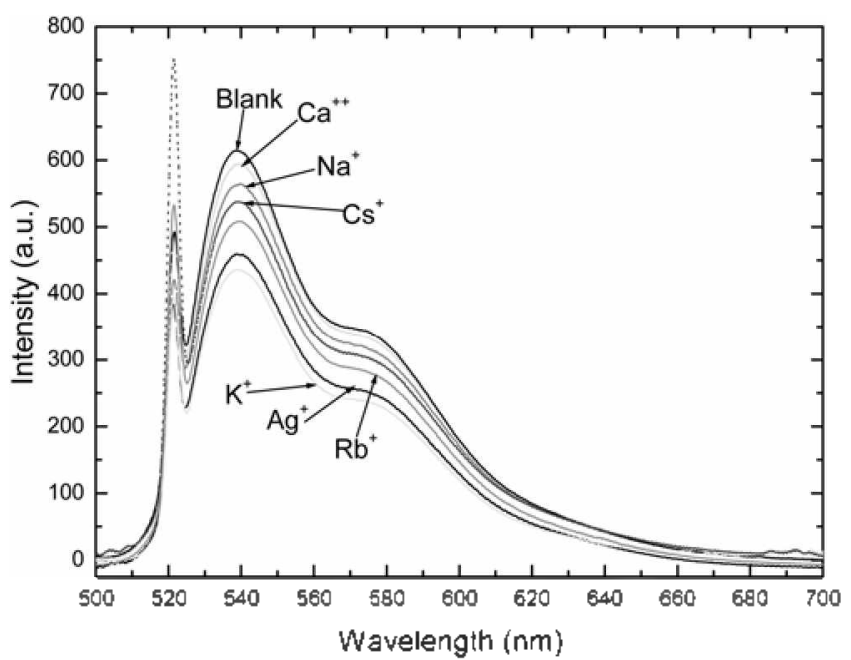

Figure 4. Fluorescence emission spectra of $4(6, \mu \mathrm{M})$ upon addition of varions metal cations ( 3 equ).

sion derived from UV-vis studies as listed in Table 1. Addition of $\mathrm{Mg}^{2+}, \mathrm{Ca}^{2-}$ and $\mathrm{S}^{2-}$ also induce emission changes. but the enission intensity is slightly decreased.

3 displayed large chelation-enhanced quenching effect with $\mathrm{Ag}^{-}$. It is known that silver ion locates in the azacrown cavity at neutral $\mathrm{pH}$. but by protonation it moves to the other part through the calixtube because of significant repulsion between ${ }^{+} \mathrm{N} \cdot \mathrm{H}$ and the $\mathrm{Ag}^{+}$ion. ${ }^{13}$

Very similar results are observed upon addition of alkali metal ions $\mathrm{Na}^{+} . \mathrm{K}^{-}, \mathrm{Rb}^{+}$and $\mathrm{Cs}^{+}$to + in acetonitrile. The sequence of enission intensity for alkali metal cations is $\mathrm{Na}^{+}$ $<\mathrm{Cs}^{+}<\mathrm{Rb}^{-}<\mathrm{K}^{+}$with polymeric fluoroionophore + as shown in Figure 4. The azacrown cavity (ca. 3.6-4.1 A) of $t$ is relatively larger than the $\mathrm{K}^{-}$ion $(2.76 \AA)$, it strongly recognizes the $\mathrm{K}^{-}$ion because of an electrostatic interaction between the azacrown cavity. ${ }^{13.54}$

Although calix-bis-azacrown-5 have two cavities that can simultaneously capture two metal ions. they have shown to have even worse extractability than calix[4]monocrown. probably due not only to electrostatic repulsion between the two metal ions but also to an induced conformation change that does not favor binding of the second metal ion. ${ }^{35}$ The repeating unit in polymer 4 can capture only one metal ion whereas 3 have two azacrown cavities that can capture two metal ions. Thus the strong fluorescence quenching effect was expected in 3.

Polymer 4 also shows fluorescence decreasing effects with $\mathrm{Mg}^{2-}, \mathrm{Ca}^{2-}, \mathrm{Sr}^{2-}$ and $\mathrm{Ba}^{2-}$ in acetonitrile. It has been shown that $\mathrm{Mg}^{3+}, \mathrm{Ca}^{3-}$ and $\mathrm{Sr}^{3+}$ were slightly decreased for the polymert.

Aftempts to observe any change in the fluorescence intensity of 4 was performed upon the addition of $\mathrm{Ag}^{-}$ion in acetonitrile. $\mathrm{Ag}^{+}$ion showed a $20 \%$ variation. In the case of trivalent ions, fluorescence intensity was decreased even at low concentration ( 1 or 2 equivalent of host molecule) of metal ion because of charge-dipole interaction between the cavity and ion. But the overall emission changes were unsatisfactory: 11,10 and $5 \%$ reduction for $\mathrm{Al}^{3-}, \mathrm{Eu}^{3-}$ and

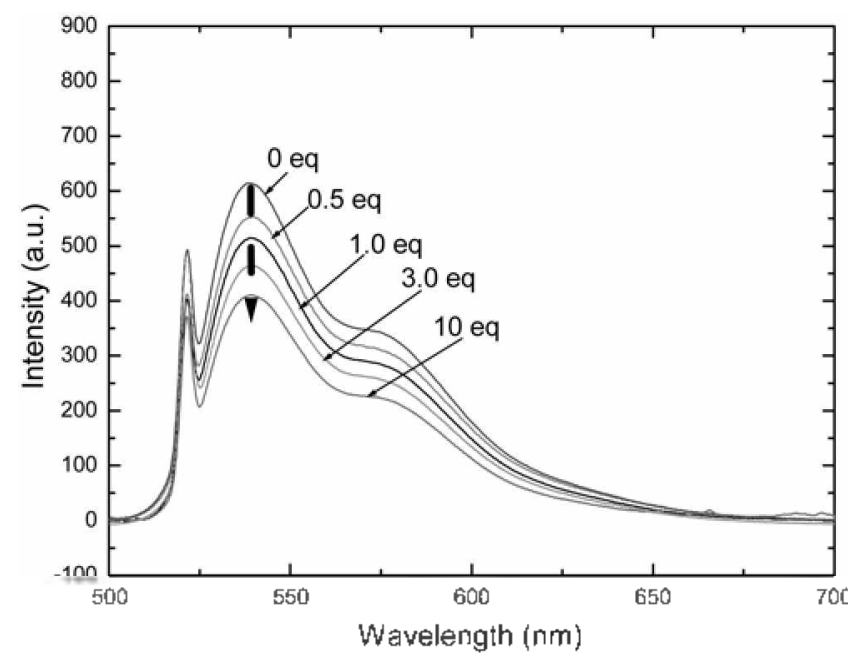

Figure 5. Fluorescence intensity change according to the amount of acid for 4.

$\mathrm{Cr}^{3-}$ ion, respectively.

When trifluoroacetic acid was added to 4 , the peak at 522 $\mathrm{nm}$ decreased apparently probably because of protonation on the amino group decreased the photoinduced charge transfer (PCT). As pH of the solution decreased. the fluorescence intensities of 3 and $\boldsymbol{t}$ decreased due to the protonation of the tertiary amine group. Upon addition of the strong acid to a solution 3 and $\boldsymbol{t}$, the emission is decreased by $37 \%$ as shown in Figure 5.

In conclusion. we have synthesized new calix[4]azacromnbased perylene model and polymeric fluoroionophores and studied binding behaviors toward metal ions via absorption band shifts as well as fluorescence changes. Addition of $\mathrm{K}^{-}$ or $\mathrm{Ag}^{-}$ion to the ligands resulted in a blue-shifted absorption and decrease of fluorescence.

Acknowledgement. This work was supported by Korea Research Foundation Grant (KRF-2004-C00366).

\section{References}

1. Shahrisa, A.: Banaei, A. Holectles 2001, 6.721

2. Xia. W. S.; Schmehl, R. H. Li, C. J. Tetrahedron $\mathbf{2 0 0 0}, 56,7045$.

3. Huszthy. P.: Kontos. Z.: Vermes. B.: Pinter. A. Tetrahedron 2001. 57.4967.

4. Xue. G.: Bradshaw. J. S.: Dalley. N. K.: Savage. P. B.: Izatt. R. M.: Prodi, L:; Montalti, M: Zaccheroni. N. Tetahedron 2002, 58. 4809.

5. Kawai. H. Nagamura. T. Mori. T.: Yoshida, K. J. Phys. Chem. A 1999. 6.660.

6. Oguz. U.: Akkaya. E. U. Tetrahedron Letf. 1998. 39.5857.

7. Alonso. M. T.: Brunet. E.: Juanes. O.: Rodriguez-Ubis. I. C. J. Photochem. Photobiol A: Chemistry 2002. 147. 113.

8. Chen. C. T.; Huang, W. P. J. Am. Chem. Soc. $2002,124.6246$.

9. Linnane P.: Shinkai, S. Tetrahedron Lett 1995, 22. 3865.

10. Kim. T. S.: Lee. W. K.: No. K. H.: Zouhair. A.: Jacques. V. Tetrahedron Lett. $2000 .+13.3345$.

11. Erk. C. Eng. Chent. Res 2000. 39.3582

12. Kim. J. S. Shon. O. J; Rim. J. A.; Kim. S. K; Yoon. J. Y. J. Org. Chem. 2002, 67, 2348 .

13. Kim. S. K.: Lee, S. H. Lee, J. Y.: Bartsch, R. A.: Kim, J. S. J. Am. 
Chem. Soc. 2004. 126. 16499.

14. Kim. S. K.: Bok. J. H.: Bartsch. R. A.: Lee. J. Y: Kim. J. S. Org. Lett. 2005.7 .4839

15. Aoki, I.: Sakaki, T.: Shinkai, S. J. Chem. Soc. Chem. Commm. 1992, 730 .

16. Ji. H.-F.: Brown, G. M.: Dabestani, R. Chem. Commm, $1999,609$.

17. Leray, I.: OReilly. F.: Habil Jiwan. J. L.: Soumillion. J. Ph.: Valeur. B. Chent Conmunt 1999.795.

18. Böhmer. V. Angew: Chem., Int. Ed Engl. 1995.34.713

19. Nishizawa, S.: Kaneda H.; Uchida. T.; Teramae. N.J. Chem. Soc., Perkin Trans. 21998.2325

20. Hecht, S.: Vladimirov, N.: Fréchet J. M. I. J. Am. Chem. Soc. 2001. 123. 18.

21. Casnati. A.: Pochini. A.: Ungaro. R.: Ugozzoli. F.: Arnaud-Neu. F.: Fanni. S.: Schwing. M.-J.: Egberink. R. J. M.: de Jong. F.: Reinhoudt. D. N. J. Am. Chem. Soc. 1995. 117. 2767.

22. Astari, Z: Abid, R: Arnalud F: Vicens, J. J. Inchision Phenom. 1992, 13, 163.

23. Jones. G. II: Vullev. V. I. J. Phus Chem of 2001. 105.6402

24. Araujo. E.: Rharbi. Y.: Huang. X.: Ainnik. M. A. Langmir 2000. 16. 8664
25. (a) Bouquant. J.: Deville. A.: Granjean. J.: Laszlo. P. J. Am. Chent Soc. 1982. J04. 686 .

26. Marco. F.: Antonello. A.: Giancarlo. O.: Armandodoriano. B Tetrahedron Lett. 2004. 45.9015.

27. Kim. J. S.; Thuery: P.: Nierlich, M.; Rim. J. A.: Yang. S. H.; Lee J. K.; Cho. K. H.: Lee, J. H.; Vincens, J. Bull. Korean Chem Soc. 2001. 22.321.

28. Kim. S. H.: Lee. C. W.: Gong. M. S. Macrontol. Res. 2005.13. 141

29. Seol. W. H; Lee, C. W.: Yang, Y. S: Gong, M. S. Hacromol. Res. 2005. 13,427

30. Kim. S. H.: Lee. C. W.: Seol. W. H.; Gong, M. S. Bull. Komam Chent Soc. 2005. 25. 1265

31. Jeon. Y. M.: Kim. I. G.: Tang. J. K.: Chang. H. J.: Kim. Y. S.: Gong. M. S. Polnter(Korea) 2006. 30.425

32. Jeon. Y. M.; Kim. J. G.; Jang. J. G.; Gong. M. S. Hacromol. Res 2006. $1+, 663$

33. Jeon, Y. M: Lim, T. H.; Gong, M. S. Hacromol. Res Submitted.

34. Kim. J. S.: Shon. O. J.: Sim. W.: Kim. S. K.: Cho. M. H.: Kim. I.G.: Sul. I. H. J. Chem. Soc. Perkin Trons. 12001.31.

35. Valeur. B.: Leray. I. Coord Chem. Rev: 2000. 205. 3. 